\title{
Oral Hsp90 Inhibitor IPI-493
}

National Cancer Institute

\section{Source}

National Cancer Institute. Oral Hsp90 Inhibitor IPI-493. NCI Thesaurus. Code C78843.

An orally bioavailable formulation of the ansamycin derivative 17-amino-17-

demethoxyg eldanamycin (17-AG) with potential antineo plastic activity. Oral Hsp90

inhibitor IPI-493 binds to and inhibits Hsp90, which may result the in growth inhibition in sensitive tumor cell populations. Hsp90, a 90 kDa molecular chaperone, may be highly expressed in tumor cells, playing a key role in the conformational maturation, stability and function of other substrate or "client" proteins within the cell; many of these client proteins are involved in signal transduction, cell cycle regulation and apoptosis, and may include kinases, transcription factors and hormone receptors. 